\title{
Portfolios across the EFL Curriculum: Methodological Perspectives of their use in university settings
}

\author{
Portafolios a través del currículo de inglés como lengua \\ extranjera: perspectivas metodológicas de su uso en \\ entornos de las universidades
}

Received July 24th 2011/ Accepted: October 12th 2011

\author{
John J. Viáfara González \\ Associate Professor. Escuela de idiomas,UPTC \\ Tunja, Colombia \\ Email: jviafara25@gmail.com \\ María Eugenia López \\ Assistant Professor Universidad Nacional de Colombia \\ and Universidad Libre \\ Bogotá, Colombia \\ Email:melh2005@gmail.com
}

\begin{abstract}
This article emerges from the experience that two EFL university professors have accumulated for several years working with portfolios in tertiary education. Starting from the theoretical principles they have undertaken to guide their practices when using portfolios, they share their methodological procedures for ESP (English for Specific Purposes), academic literacy and teaching practicum courses. The authors describe in detail how portfolios are structured in each setting, enhancing autonomous and collaborative learning as well as the reflective teaching of the foreign language. In addition, the manuscript discusses the benefits students perceive portfolios bring since they can approach their literacy development as a process, be more creative as learners and prospective teachers, find meaningful contexts to learn and increase their metacognitive skills, among others. The pedagogical implications involve suggestions in regards to how role dynamics and power relations built around these artifacts, the need for suitable peer monitoring structures and for the creation of solid pedagogical frameworks to encourage autonomy.
\end{abstract}

Key Words: portfolios in ELT, English language teaching methodology, process writing, teaching practicum, autonomous learning, EFL in universities

\begin{abstract}
Resumen
Este artículo surge de la experiencia que dos profesores universitarios de inglés como lengua extranjera han acumulado por varios años trabajando con portafolios en nivel terciario de educación. A partir de los principios teóricos que han seguido para guiar sus prácticas al trabajar con portafolios, comparten los procedimientos metodológicos en cursos de inglés para propósitos específicos, escritura y lectura académica y práctica docente. Los autores describen en detalle como los portafolios se estructuran en cada situación promoviendo el aprendizaje autónomo y cooperativo al igual que la enseñanza reflexiva de la lengua extranjera. Además el manuscrito discute los beneficios que los estudiantes perciben en los portafolios ya que por medio de estos ellos pueden asumir su proceso de desarrollo de escritura y lectura como un proceso, ser más creativos como estudiantes y futuros profesores, encontrar contextos significativos para aprender e incrementar sus habilidades metacognitivas, entre otros. Las implicaciones pedagógicas incluyen sugerencias respecto a cómo la dinámica de las relaciones y las relaciones de poder se construyen alrededor de estas herramientas, la necesidad de estructuras de monitoreo entre compañeros que sean apropiadas y de marcos pedagógicos sólidos que motiven la autonomía.
\end{abstract}

Palabras claves: portafolios en la enseñanza de inglés, metodología de la enseñanza del inglés, escritura como proceso, práctica docente, aprendizaje autónomo, inglés como lengua extranjera en universidades 


\section{Introduction}

Along our teaching experience in various EFL settings, we have faced the challenge to strike a balance between our expectations and those of our students towards their English language learning and teaching; we have tried to merge our students' needs and interests with our experience in designing curriculum at the university level. This is particularly challenging given that university students have diverse socio-cultural origins (Álvarez et al., 2004). In particular, the universities described in this article are located in capital cities and thus have students who come from different regions of the country. In consequence, this large array of student backgrounds has encouraged us to find options to foster their EFL education.

During the last decade, Colombian EFL teacher-researchers' efforts have significantly concentrated on motivating students, supporting their development of language skills and encouraging them to assume autonomous and collaborative attitudes (Viáfara and Alvarez, 2010). As it will be discussed along this article, portfolios can precisely become an effective pedagogical strategy to foster students' centeredness, selfdirected learning, development of communicative competence and mutual learning.

In our particular case, we have implemented portfolios in three different university contexts. First, we have integrated them in English for Specific Purposes (ESP) courses in both public and private universities. In this case, learners produced both paper and electronic portfolios. Second, we introduced the use of portfolios as a means to support the writing and reading process of students working towards a degree in Modern Languages. Likewise, at the Licenciatura level, portfolios have been introduced, seeking to improve student teachers' initial EFL pedagogical practices.

The experience that we have gained from our work in the aforementioned settings has inspired us to write this paper. Our intention is to describe how we have implemented portfolios in these contexts and how students perceived that this tool has influenced their learning; Furthermore, we aim at revealing the connections that current methodological trends in EFL hold with portfolio use. Likewise, we seek to discuss the challenges this proposal implies for its adaptation to EFL settings.

This paper will start with a review of theoretical principles in regards to the use of portfolio in education. Then, we will describe and discuss the methodology employed to integrate portfolios into the classroom in each particular context. Finally, we will leave readers with a discussion of the most relevant pedagogical implications we can gather from our practices.

\section{Theoretical Principles Underlying the Implementation of Portfolios}

According to Genessee and Upshur (1996,99) "a portfolio is a purposeful collection of students' work that demonstrates to students and others their efforts, progress and achievements in given areas." The previous definition illustrates specific features that differentiate a portfolio from other common devices that store information such us folders, notebooks, computer files, USB memories and so on. Genesse and Upshur also suggest that a portfolio's layout needs a structure a folder, a hard cover or CD-ROM among others. Each portfolio gathers information for particular reasons and therefore is a systematic and continuous planning process to decide what is valuable enough to include. Most importantly, the portfolio, as an alternative means of evaluation, can characterize students' progress qualitatively as compared to a more quantitative evaluative approach.

In regards to portfolios as a means for assessment, Paulson et al. (1991, p.60) mentions how these tools can be structured to guide students' learning: "This collection must include 
students' participation in the selection of portfolio content; the guidelines for selection; the criteria for judging merit; and evidence of student self-reflection". Bearing the previous in mind, it can be stated that portfolios strengthen students' autonomy; these tools are centered on learners' efforts, interests, choices, progress and assessment (De Fina, 1992; Paulson et al., 1991).

Likewise, Valls (2008) who considers portfolios as a teaching and learning tool, remarks how these artifacts foster a collaborative relation between student and teachers; pupils and educators can negotiate how to maintain the portfolio, what to include in it, and how to assess it. Furthermore, the portfolio encourages students' self-monitoring, questioning, thinking, and analyzing processes with the end of being reflective about their own planning and performance along their personal and professional preparation.

In addition to the principles previously highlighted, Rue (2008) underlines flexibility as a necessary characteristic in portfolios. To begin with, teachers employing them need to adapt the learning context when implementing them so that these artifacts are accessible for all kinds of students. In addition, flexibility also involves, being tolerant to accept and foster learners' trials and errors as well as constant drafting which allow students to explore their learning, to make relations, analyze, contrast and integrate previous and new information.

Introducing portfolios requires selecting a typology of these tools. In general Genessee and Upshur (1996:99) mention two main groupings of portfolios with regard to their scope: specific and broad. The first one refers to a portfolio that explores a particular area of interest, such as writing. The second involves wider aspects of language development: students' needs and interests. Danielson and Abrutyn, (1997) refer to another classification of portfolios according to their purposes. In the general EFL setting, the first type, the working portfolio, can reveal students' progress in regard to their language practices. The second one, display portfolios, collects students' best work, which leads to the assessment of students' achievements along the course.

\section{Introducing portfolios in EFL university courses}

General guidelines given to the students regarding their portfolios were similar in all three contexts described above. Portfolios were introduced during the first session of the course. Teachers made sure that students understood how to get started: what portfolios were, the different types of portfolios and the quantity of information each portfolio could contain. ESP and Teaching practicum courses incorporated working portfolios with a broad scope while the academic literacy course included a working portfolio with specific focuses (reading and writing). Samples of previous students' portfolios were shared and then various handouts were given to the students to help them organize and store their material, and reflect upon their production. In addition, evaluation criteria based on form and content were also explained.

\section{Portfolios in ESP courses}

\section{The Context}

Portfolios were implemented for a period of six semesters in two private higher education institutions and a public university. Participants were first through fourth semester students of basic and pre-intermediate English courses. They were enrolled in different academic programs where English was taught for specific purposes (ESP). Their exposure to English in classes was about 4 hours per week. Groups in the two private universities had an average of 20 students per class whereas 40 learners per class was the average in the public higher education 
institution. English courses were not part of the students' major area of study and oftentimes learners regarded them as a mere pre-requisite for graduation purposes. It was our impression that previous situation seemed to reduce students' engagement in learning the foreign language.

These courses integrated the principles of communicative language teaching, collaborative work, and autonomous learning, among other ELT approaches. Teachers worked with textbooks, worksheets, CD-ROMs and language labs. The portfolio was used as an alternative tool for assessment which was graded as part of students' class work. Learners had not had any previous exposure to the use of portfolios.

\section{Keeping the Portfolio: Process and Structure}

The main goal in these courses was to guide learners to develop communicative competence in English to study the content of subjects and interact with others in relation to specific academic fields. In this regard, portfolios sought to provide an opportunity for participants to select specialized material and expand their knowledge of jargon and subject matters in learners' areas of expertise. As a complement of the previous objective, using everyday English also emerged as a relevant part in syllabuses.
Based on our experience as university Professors for ESP courses, we perceived that in certain cases students started these courses with a low motivation to learn the language. Therefore, an additional objective of integrating the portfolio into these courses was to increase learners' awareness of the importance of learning the foreign language. As they worked in their portfolios, students could become aware of the variety of contexts in which English can be used and the benefits that learning this foreign language could bring to their lives.

It is worth noting that students' concerns and opinions were taken into account when creating the portfolio guidelines. Students chose the format they wanted to adopt for their portfolios: paper or digital versions. The latter ones gained popularity as technology became more familiar or students and as it was increasingly used in their specific academic areas. The use of technology made them more interested in learning the foreign language.

In general, participants enjoyed adding a personal touch in their portfolios to identify themselves; most of the times they reflected their personalities and skills, in their decorations. The following chart reveals teacher and students' participation in establishing portfolio guidelines:

Table 1. Teachers and students' decision making in establishing portfolio guidelines

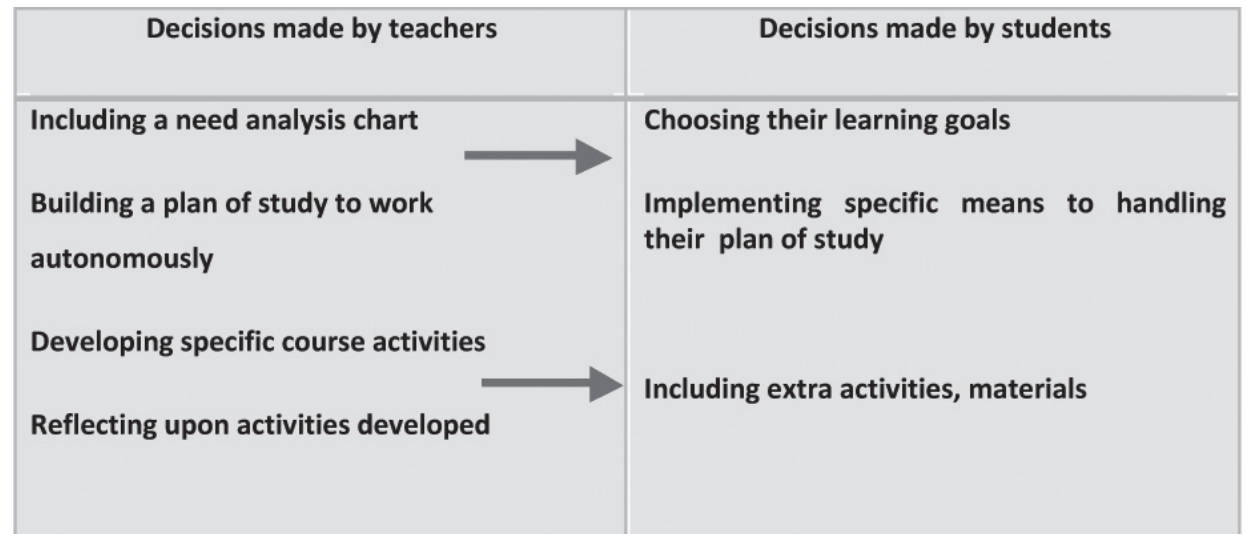


In the specific case of ESP courses, this new tool helped to guide individual learning through several steps. Firstly, students were taught what a learning goal was and how to create their own. For instance, some students stated that they had difficulties in listening as part of their need analysis, therefore they looked for a motivating practice; since they liked music which revealed their interests and engagement with the activity, they chose to work on songs practice. By means of the goal they set in the previous section, participants then created a plan of work for selfstudy (see appendix 1).

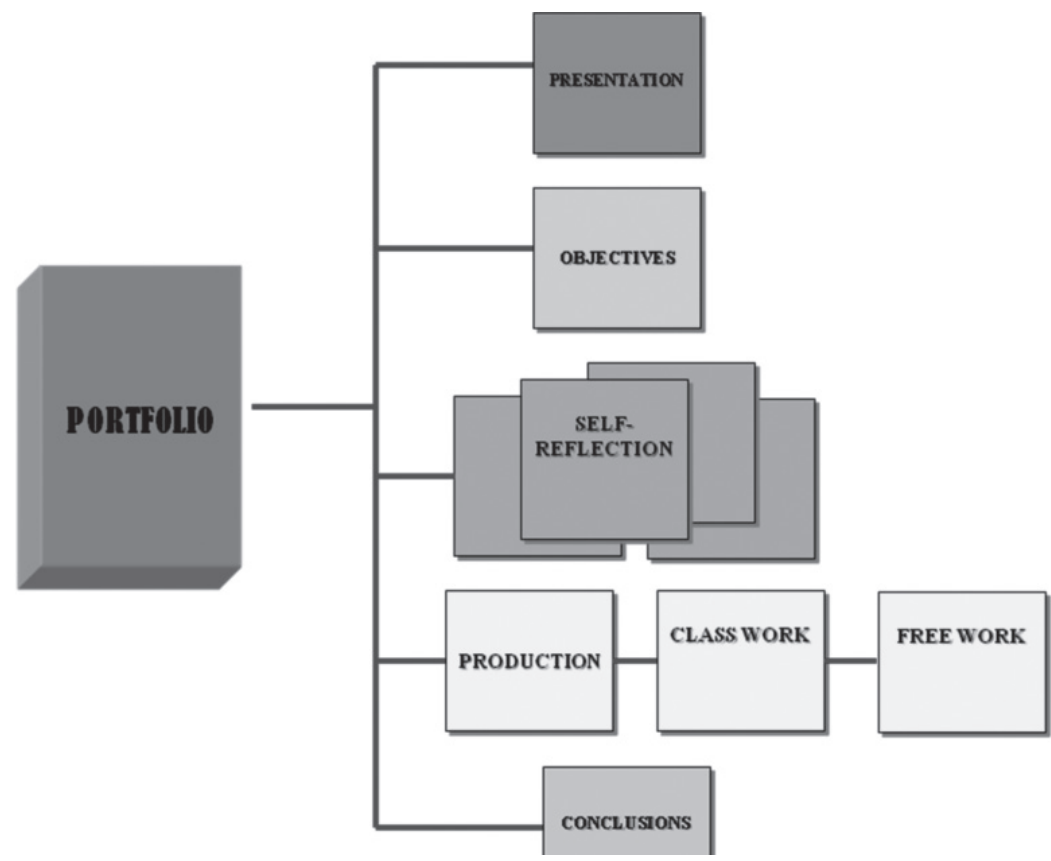

Figura 1. Esp courses portafolio organizational layaout

Thirdly, students freely selected class and independent work through the course of the term to include in their portfolios; this fact left evidence of the learning path they went through; this also provided teachers some reflection to check their current methodology and make some decisions on the spot to update and improve their classes. For instance, when learners chose mainly grammar practice activities based on the mechanical completion of sentences, that led us to analyse if that was the model our classes favoured or it was a working pattern they had adopted from previous experiences.

Fourthly, portfolios incorporated opportunities for learners' self-reflection. In this way, they counted with opportunities to constantly analyze their strengths, weaknesses and suggestions of how to overcome their limitations. Student's self-evaluation tool and portfolio forms provided by the teacher, guided these reflections and helped to determine the criteria to be used by the teacher's assessment.

In general, evaluation was regarded as a process and was guided by self-assessment, but it also included peer and professor evaluation. Once participants had started keeping their portfolios, they were asked to bring them to class at least three times per term, so that they could be shared with their teacher and classmates. This kind of requirement contributed to keeping students 
constantly focused on their portfolio and reduced the risk that portfolios would be done at the last minute. Participants filled in a self-evaluation format, which contained various criteria based on the sections of the portfolio. Then, peer evaluation took place by means of another format. Finally, the professor, taking into account the other evaluations provided his own, and assigned a grade along with recommendations for improvement. Evaluation formats included a space for qualitative assessment in which participants described their work, support their judgment by means of evidences and included suggestions (see appendix 2).

\section{Portfolios in an EFL Undergraduate Academic Literacy Course}

\section{The Context}

For three years, portfolios were a nuclear part of an academic reading and writing course called Communicative Project VII, of the Modern Languages program in a public university, which prepares students to be high school English teachers. The course was the last English level for prospective teachers. Students had face to face classes five hours per week. The classes usually had between 25 and 30 students. Given such little in-class time, it was expected that students worked autonomously outside of class. Students expressed that along their studies they had had various experiences with portfolios, some of them more successful than others.

The Communicative Project VII course aimed at supporting students' development of their language proficiency in general; however, academic reading and writing were the focus of the class. This is not to say that other skills were not fostered but rather that speaking and listening were favored as they supported students' academic literacy development. At this point in pre-service teachers' preparation, it was expected that they had mastered the academic language required to write and read documents in relation to EFL pedagogy.

Process writing and reflective reading were the main approaches promoted in the course to guide students' literacy development. Starting from a diagnosis of their reading and writing habits, learners studied in detail various writing and reading techniques. Throughout the course, they developed academic texts, which were revised by themselves, their professor, and their peers. Additionally, they produced a miniresearch project in relation to pedagogical issues. Finally, students were given workshops about formal aspects of the language to support their mastery of English language structures.

\section{Keeping a portfolio: process and structure}

The purpose of requiring student teachers to keep portfolios in this course was to provide out-of-class spaces for free practice; students were expected to put reading and writing theory into practice and increase their exposure to the language. Additionally, since their literacy experiences in class were usually monitored by their teacher and limited by task requirements, the implementation of portfolio sought students' spontaneous creation and interpretation in composition pieces that were not limited by the classroom setting. Bearing this in mind that a goal of portfolio implementation was to guide students into structuring their autonomous practice, student teachers employed EFL principles to their own learning, self-discipline, reflection and evaluation of their literacy level.

General guidelines to start the portfolio with student teachers were similar to those described in the previous section; however, based on the nature of the course, student teachers used the portfolio to not only address their specific interests in academic reading and writing, but also in other aspects of their English learning as the ones in the 
aforementioned purposes. In regard to portfolio management, the next chart shows the decisions the course teacher made and the ones students assumed.

The portfolio included several sections. To being with, learners were encouraged to keep written reflections upon their development of literacy skills or life topics of their interest such as their feelings, the role that meaningful people have played in their lives, or materials and approaches used for their learning. These journals were shared with peers and professors and were connected with stages in their writing process. For example, they were asked to review previous journal entries and to determine, by themselves or with the help of peers, weaknesses in their writing; then they were required to produce an improved version of writing pieces. Upon examination of portfolios, it was found that students used them to practice specific language points, to monitor their learning, or to self-correct their writing.

Table 2. Teachers and students' decision making to establish how the portfolio would be kept

\begin{tabular}{|l|l|}
\hline Decisions made by teachers \\
Including a journal \\
Building an autonomous work plan \\
Sharing their portfolio with peers
\end{tabular}

In another section pre-service teachers were asked to include their weekly objectives for improvement based on their own needs. They included a set of concrete activities to reach these objectives. Finally, they self-evaluated how they perceived their work and they included evidence of their work. Based on how the teacher perceived student's autonomous practice, he provided feedback on how to improve the setting of work objectives, self-assessment, and strategies selected to achieve such objectives. Though the main purpose was to foster students' writing and reading, learners generally decided to design activities to practice all four language skills, grammar and vocabulary. Students' resourcefulness to propose activities for their independent work was notorious: they recycled materials from previous courses to connect them with current topics, included extra theory and worked on material about their own interests.

The third section was an extension of inclass- activities. In the case of reading, on a weekly basis, they shared their favorite readings with a group of peers. From this exercise, they prepared a reading log to be included in their portfolios that was based on the main ideas extracted from texts and their discussions with peers. In addition, they wrote a reflective piece to further analyze the text's topic.

Section four kept student-teachers' assignments as for example: compositions, worksheets, 
evaluation and exercises. In order to encourage students' reflection upon their writing process, they selected certain assignments that they considered to have been the most enriching and included a written reflection upon them. They frequently ponder about their performance on evaluations, how specific exercises contributed to their growth, or their likes and dislikes in regards to course assignments.

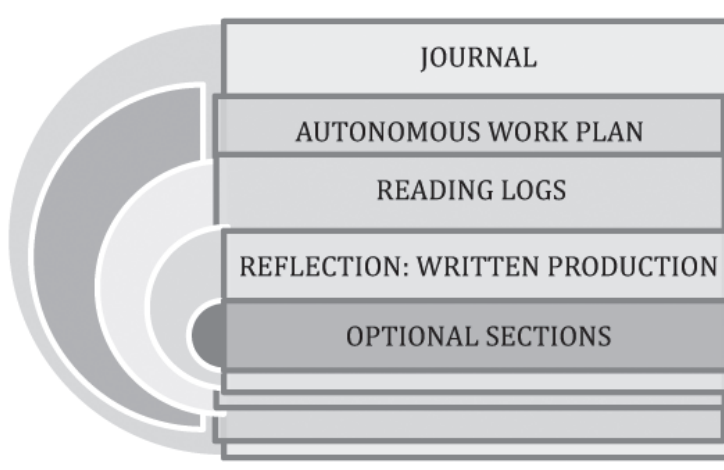

Graph 2. Modern Languages Program Academic Literacy Course Portfolio Organizational layout
Finally, student teachers had the option to add any other section they regarded as relevant. Usually partners' feedback, a collection of readings, guidelines for correcting their own work, indexes of frequent limitations in their writing and study agendas were part of these attachments (see appendix 3).

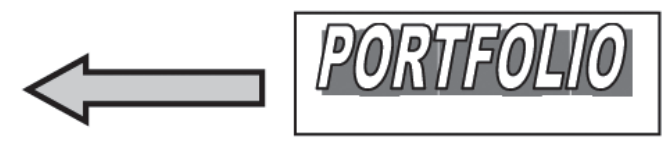

\section{Gains and Suggestions}

In order to evaluate this experience, surveys were applied during four semesters to participants. Students claimed that they benefited from the possibility to monitor their writing development by means of their portfolios. Likewise they mention that they realized how their composition process evolved throughout the course of the semester. This matches the findings of Williams(2005), Pertuz (2006), Bintz and Shakes (2005) who consider that these artifacts are consistent with a process oriented practice. These authors considered that portfolios can stimulate learners' continuous assessment of their sequential texts drafts. Focusing students on drafting can make them aware of the relevance of this stage for writing and increase their chances to adopt this strategy as a habit. Given that the drafting process regards mistakes as opportunities for improvement rather than punishment, drafting can lower anxiety towards being evaluated. Portfolios also support the process of writing by engaging students in the search for information, the generation of ideas and the organization of texts.

Furthermore, students valued that through reflection in journals, they could write freely and creatively about how they had overcome their difficulties with regard to grammar, punctuation, spelling and paragraph construction. A study developed by Paesani (2006) revealed that portfolios facilitate the contextualization of grammar learning and serve as models for students' writing since they keep samples of texts 
inside them. Pertuz (2006) claims that, in this way, this tool allows students to think critically about their language competencies and to change their negative perception about their own writing performance. Finally, Paesani (2006) refers to the integrative development of writing and reading that portfolio work can foster.

As a suggestion, participants pointed out the need to include more people as tutors to provided feedback on their portfolio. This reflects Paesani (2006) and Bintz and Shakes's (2005) warnings about problems teachers can have in organizing peer revision alternatives: peers tend to focus more on form rather than content and they sometimes do not provide detailed feedback. These scholars also suggest that three person peer review groups can greatly assist in overcoming these challenges.

\section{The Role of Portfolios in Recycling Reflections along the Teaching Practicum}

\section{The Context}

The teaching practicum for foreign languages programs in public Colombian universities are structured under different conditions from one institution to another. This is evidenced by the differences in the two settings described below. On one hand, in the first institution, students need eight semesters to get their diploma and the practicum takes place in the seventh semester. Student teachers have to teach four hours of English per week and they are not required to spend the whole shift at the school, therefore rarely taking on additional duties outside of their agreement.

On the other hand, in the second institution, prospective teachers enroll for their teaching practice in tenth semester, the final one of their major. They teach eight hours per week and they work on different school duties during their daily shift. In both programs, student teachers attend a weekly counseling meeting in which they have to submit their lesson plans for advice. Likewise, they reflect upon topics of relevance for the practicum with their advisor as well as peers; this deliberation is substantially guided as preservice teachers prepare a portfolio. Secondary school cooperating teachers contribute to support pre-service teachers' ELT preparation in one of institutions since they have a degree on that area, whereas primary school cooperating teachers can not usually coach them given their more general pedagogical preparation.

\section{Keeping a Portfolio: Process and Structure}

The reflection generated by means of portfolios seeks to provide future teachers opportunities to look at their own practices within their teaching contexts. This kind of exploration can lead prospective teachers to identify relevant learning factors affecting their work and to explore their strengths and weakness as teachers.

As part of their teaching practicum general guidelines, participants were informed of how the advising processes had been conceived to support them. The following diagram shows the different elements that the student teachers' portfolios, a fundamental piece in their reflection, comprised:

At the beginning, student teachers took part in a self-awareness session to determine their needs and interests as future teachers. Once they had identified some key issues to tackle in regards to lesson planning, material design, classroom management and evaluation, among others, they were advised to design a weekly plan which would be monitored by means of their portfolio. In this way, they organized their time and activities in the practicum. This autonomous learning plan was similar to the ones described above in the ESP and EFL context with one addition: a section to 


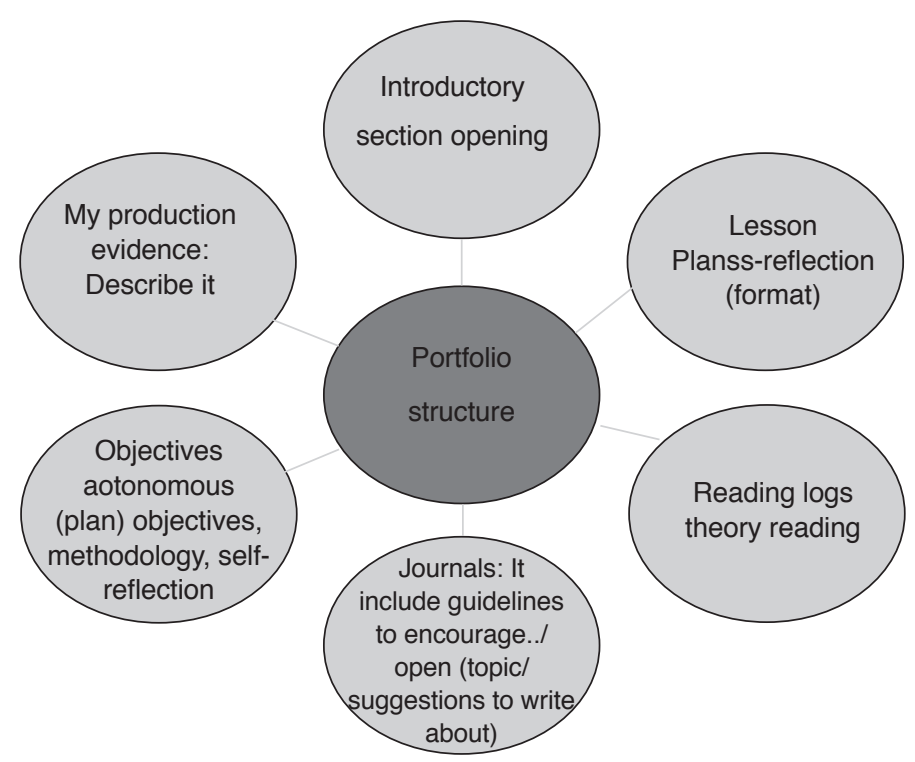

Graph 3. Sections included in portfolios used in pre-service teachers' practicum

include the pedagogical implications of their work and suggestions for future teachers.

Bearing in mind that portfolio work requires student teachers to be honest and open in reflecting, both structured or non-structured reflection formats supported prospective teachers' analysis. On the one hand, structured reflective activities provided guidance to new users who were not accustomed to this kind of exercises; such writing was meant to help them become aware of options to achieve a detailed description and analysis of their pedagogical practice (see appendix 4). On the other hand, a non-structured reflective activity was expected to lead student teachers to more open ways to gather ideas during their reflection. When using this format, tutors provided only general guidelines.

Among the reflective activities, journals were centered on pre-service teachers' deliberation upon specific classes or general situations of school life. It was expected that student teachers writing guided them to discover relevant aspects in their job and to face difficulties as novice teachers. Systematizing these problematic areas became a strategic activity to help pre-service teachers keep in mind the most pertinent issues in designing and delivering classroom material. Specifically, students read their weekly reflection and extracted those issues which often caused them trouble to create an index.

As several of the concerns pre-service teachers expressed in their journals involved lesson planning, student teachers developed a format to look chronologically at their progress in this matter. They had to compare the various drafts of their lesson plans which included their counselor's feedback. This exercise included looking at how to organize their classes, formulate of objectives, contextualize the lesson, and develop activities. In this way, they could see how they have evolved in their organization over the course of the semester (see appendix 5).

To fuel their reflection, pre-service teachers were also requested to analyze ELT principles. Ideally this would lead them to integrate their practices with ELT theory. However, it seemed to be difficult for pre-service teachers to put theory into action. For this reason, we 
incorporated an exercise in which pre-service teachers wrote analytical summaries of course readings. Participants wrote summaries about the pedagogical implications of the documents they found most relevant to their own teaching, contrast them with other pedagogical theories and what actually took place in their classrooms. This exercise helped them to evaluate their own teaching and raised their awareness about factors around theory applicability.

\section{Gains and suggestions}

Several formats included and filled by student teachers in their portfolios revealed their perceptions in regard to the effect the portfolio had on their teaching preparation process. They commented that through self-reflection upon their performance, they became more open to expressing their feelings and being critical about key issues of learning and teaching in EFL pedagogy. Gradual and continuous reflection contributed to changes and growth because they broadened their views towards their performance; the student teachers remarked that they assessed their performance, improved their future lessons and gained confidence in their practicum. Moreover, through designing the portfolio, student teachers claimed that they learnt about their own beliefs and this helped them to be more conscious about what one learns, how one learns and why one learns. In other words, through the use of the portfolio, knowledge building was facilitated.

Another benefit Student teachers underlined was the support portfolios provided them to connect theory with practice. The aforementioned ideas are supported by Klenowski (2000) who expressed that portfolios not only encourage practitioners to question their assumptions and values, but also help them to integrate theoretical knowledge with options for practice. For prospective teachers connecting theory and practice seemed to be difficult because they might lack experience, knowledge of context and familiarity with the pedagogical literature. Barak (2005) emphasizes that

"learning to be a reflective practitioner
includes, not only acquiring technical
expertise, but also the ability to engage in
dynamic professional relationships and to
establish meaningful connections between
theory and practice, providing a rationale
for practice" (p.27).

Likewise, by self-evaluating and monitoring their teaching through their portfolio, participants claimed they strengthened their lesson planning, organizational, questioning and teaching strategies as well as their skills to manage their students' behavior.

Portfolios also helped student teachers to keep a record of real teaching resources they had used, including the materials they had designed. In this way, the portfolio revealed their creativity and their incorporation of principles behind material preparation, its design and its rubrics. In this vein, as cited by Ariza and Viáfara $(2004,35)$, "Portfolios should be seeing as an essential tool which might provide future teachers with materials to be evaluated, adopted or adapted in their professional practices".

\section{Conclusions and Pedagogical implications}

Including portfolios in the EFL curriculum of three different university programs have led us to acknowledge how reflection, alternative assessment, autonomous and collaborative learning can buttress students' learning. These approaches came together in order to make of portfolio's implementation a powerful tool in facing many of the challenges we usually encounter in the teaching and learning of English as foreign language.

In our implementations, providing different options to work with portfolios expanded the chances to involve students in reflective learning and teaching experiences that could suit their 
personal style. We acted as mediators between these artifacts and participants so they wrote spontaneously, used formats or conducted other kind of exercises to elaborate their thinking and analysis of various aspects in their knowledge building.

Taking into account that different reflection formats provide spaces for students to think about particular learning concerns, we sought to engage students in continuous reflection as they kept their portfolios. Thus, they could go over conflictive issues several times using a broad variety of related activities. This allowed them to deepen into situations, avoiding a common limitation underlined by Barak's (2005) when he talks about the basic level of reflection student teachers usually obtained as they work with portfolios. The author remarks that this kind of shallow analysis consists of explanations of their actions and feelings supported by their personal judgment, beliefs and opinions. Dialogic reflection, a deeper analysis of possible reasons for events and actions, and critical reflection which implies to look at their actions from the broader historical, social, ethical and political perspectives should be promoted.

Since we regarded students' self-assessment as a realization of reflection by means of portfolios, we encouraged participants to constantly monitoring what they learned, how they learned and what factors contributed to their learning. Taking into account that in our country foreign language teachers are strongly rooted in traditional evaluation methods (Muñoz,2009;Lopez and Bernal,2009), portfolios emerge as a possibility to familiarize participants with diverse assessment instruments. Generally, students developed their portfolio keeping skills by using qualitative evaluation. This encouraged a move from summative to formative evaluation. In our experiences, the development of communicative and teaching skills entailed the use of process approaches. For this reason, adopting a process perspective for evaluation was a suitable option.

Nonetheless, this evaluation approach was challenging for participants; they found it difficult to depict in detail their achievements and failures and to deepen into the causes of their results. Likewise, close relations among students sometimes caused their limited provision of feedback to peers since they did not have enough knowledge to identify problems or they felt uncomfortable in judging their classmates' performances. The teacher, as a mediator in the development of portfolios, needs to provide guidelines to students with specific reflective points to tackle critical learning issues. Furthermore, additional mechanisms to ensure trustworthiness in peer-evaluation, for example involving more than one partner in assessing a portfolio and monitoring on the teacher's part, can improve this process.

EFL settings require the provision of constant outside classroom language practice as a means to complement the limited number of hours of face-to-face instruction. With this in mind, one of our objectives was to show students options for autonomous work. Thus, in our settings, we prepared the introductions of portfolios in the classroom, starting with a purposeful outline of the stages to guide them in how to plan and assume their own learning from their needs and interests. This kind of procedure exemplifies how students can develop the necessary discipline to undertake meaningful autonomous learning experiences.

Assuming collaborative attitudes also helped us to guide these experiences; we tried to negotiate specific contents, procedures, strategies and structure for portfolio construction with learners. Barak (2005) explains that projecting power relations in a shared enterprise between 
teacher and students through portfolios can make students more responsible for their own learning. Moreover the previous fact, along with their perception of their own progress increase their motivation, which in turn stands as a fundamental condition to work autonomously.

We would like to close by remarking on the impact of portfolios in our work as tutors. Similarly to what Klenowisky (2000) mentions, we perceived that professionals in charge of supporting students in general through portfolios also learnt from this experience. We felt more motivated and comfortable to conduct our job since portfolios matched most of our pedagogical principles. We noticed that these tools guided us to make more comprehensive use of evaluation procedures. Providing future teachers more clear and detailed explanations and working collaboratively by sharing ideas among staff were also gains we perceived.

\section{REFERENCES}

Álvarez G. M. et al. (2004). Manual de tutoría universitaria. Barcelona: Octaedro.

Arter, J. \& Spandel, V. (1992). Using portfolios of student work in instruction andassessment .Educational Measurement: Issues and Practice, 11 (1) , 36-44.

Ariza , A. \& Viáfara, J. (2004). Involving students in evaluation of course aims through their perception of material field in portfolios. How, 11, 24 -36.

Barak,L. (2005). Portfolios as evidence of reflective practice: What remains untold. Educational research,47(1),25-44.

Bintz, W. \& Shakes,M. (2005). From university to classrooms: A preservice teachers' writingportfolio program and its impact on the instruction in teaching strategies for writingportfolios in the classroom. Reading Horizons, 45 (3), 217-233.

Castro, L. (2002). El portafolio de enseñanza como herramienta y texto para la reflexiónpedagógica. Perspectiva Educativa, 3, 9-20.
Danielson, C. \& Abrutyn, L. (1997). An introduction to using portfolios in the classroom. Alexandria, VA: Association for Supervision and Curriculum Development.

De Fina, A. (1992). Portfolio assessment: Getting started. New York: Scholastic.

Genesee, F \& Upshur, J.A. (1996). Classroom-Based evaluation in second language education.Cambridge: Cambridge Language Education Series.

Klenowski,V. (2000).Portfolios: promoting teaching . Assessment in education, 7(2),215-237.

Little, D. (2009). Language learner autonomy and the European language portfolio: Two L2English examples. Language teaching. 42(2), 222-233.

Lopez, A. \& Bernal, R. (2009). Language testing in Colombia: A call for more teachereducation and teacher training in language assessment. PROFILE, 11 (2), 55-70.

Muñoz, J. (2009). Exploring teachers' practices for assessing reading comprehension abilities in English as a foreign language. PROFILE, 11(1), 71-84.

Paesani, K. (2006). Exercise de style: developing multiple competencies through a writingportfolio. Foreign Language Annals, 39 (4)),618-639.

Paulson F., Paulson, P. \& Meyer, C. (1991). What makes a portfolio a portfolio? EducationalLeadership,48,60-64.

Pertuz, W. (2006). El portafolio: un diálogo necesario para la cualificación de la escritura.Zona próxima , 7, 50-61.

Rué, J. (2008) El portfolio del alumno, herramienta estratégica para el aprendizaje. Aula delnnovación Educativa, 169, 29-33.

Valls, G. (2008). Una aproximación al concepto de portafolio del alumnado. Aula de InnovaciónEducativa, 169, 34-38.

Viáfara, J. \& Álvarez, J. (2010). EFL in Colombia: a state of the art from ten years ofeducators publications. Paper in: 2nd Coloquio Internacional Sobre Investigación en LenguasExtrajeras. Universidad Nacional.

Williams, J.(2005). Teaching writing in second and foreign language classrooms. Boston: Mc GrawHill. 


\section{Appendix 1 \\ Student Plan of Work in an ESP Course Portfolio}

My Plan of Work

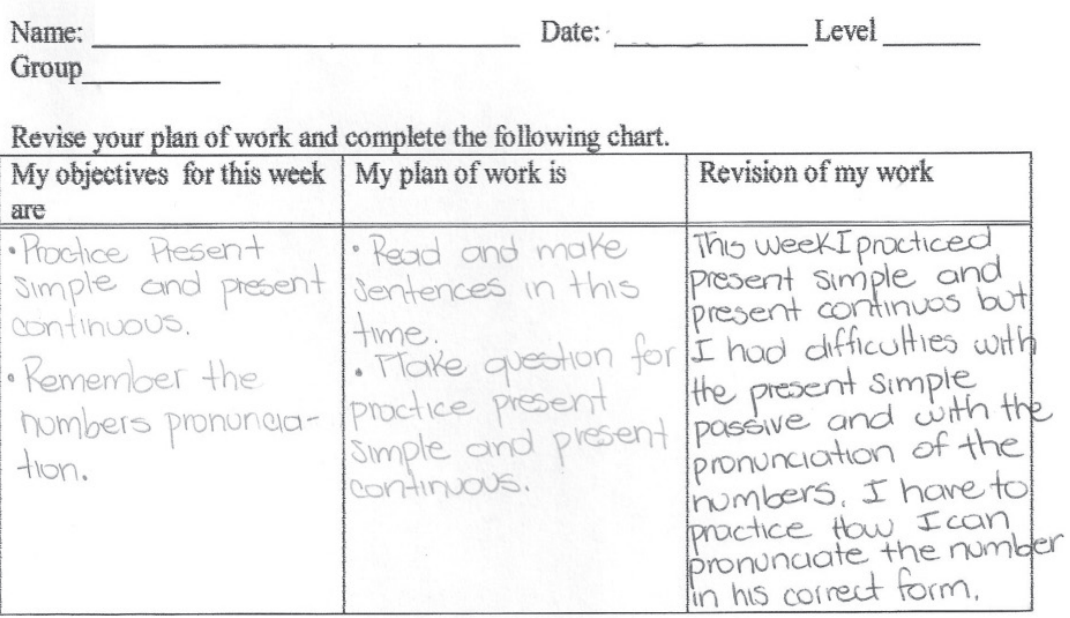

Appendix 2

\section{Portfolios Evaluation Formats ESP and Academic Literacy Course}

Portfolio Peer Revision

Your Name

Date Section:

Your Partners' Name

Look at your partner's portfolio. Revise each one of the sections listed in the chart. Based on the criteria provided at the beginning of the course for each section, mark the corresponding column to signal if your peer has worked in the section or not. Then, write comments to specify what you think are strengths, the problems you could find and how they can be improved.

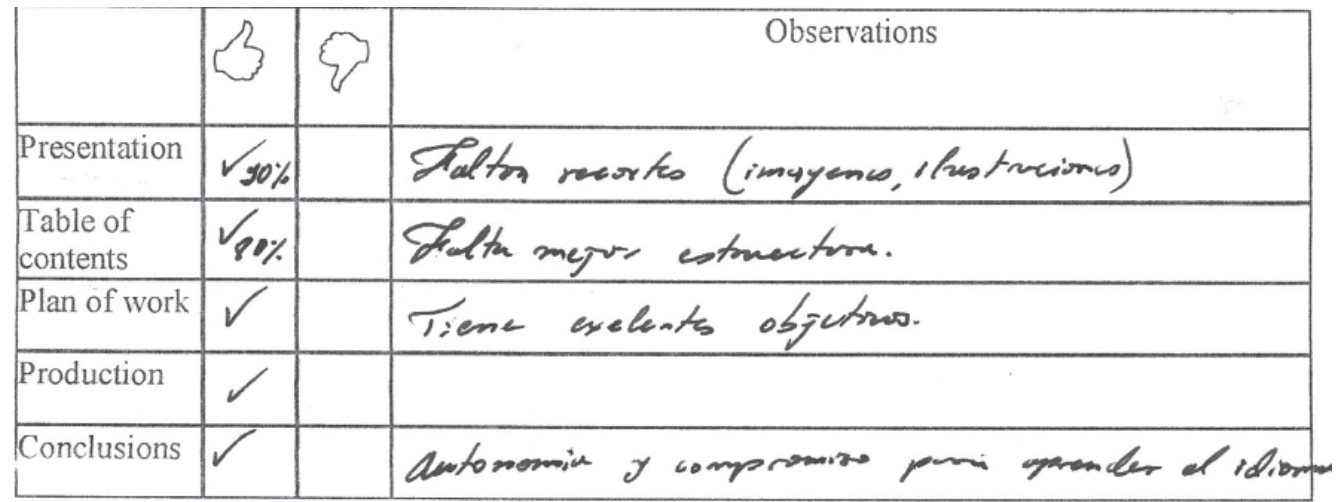




\title{
Appendix 3.
}

Format for Optional Activities included in Portfolio

\author{
FREE ACTIVITIES FORMAT
}

Name:

Date:

Skill:

Title:

Activities let dos artíclos, uno de pslologíu de la

salud y otro del uso de la masica en el apreadizuje

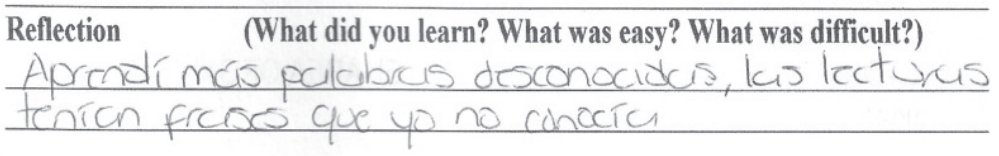

Aspects you would like to improve in future practices.

Leer menos antroblos, pero reculizur més cuncienstamente una lectura tembien empezer a aprenderne kis polubras que no entendi

\section{Appendix 4.}

Structured Form to Support Reflection through Journal Writing

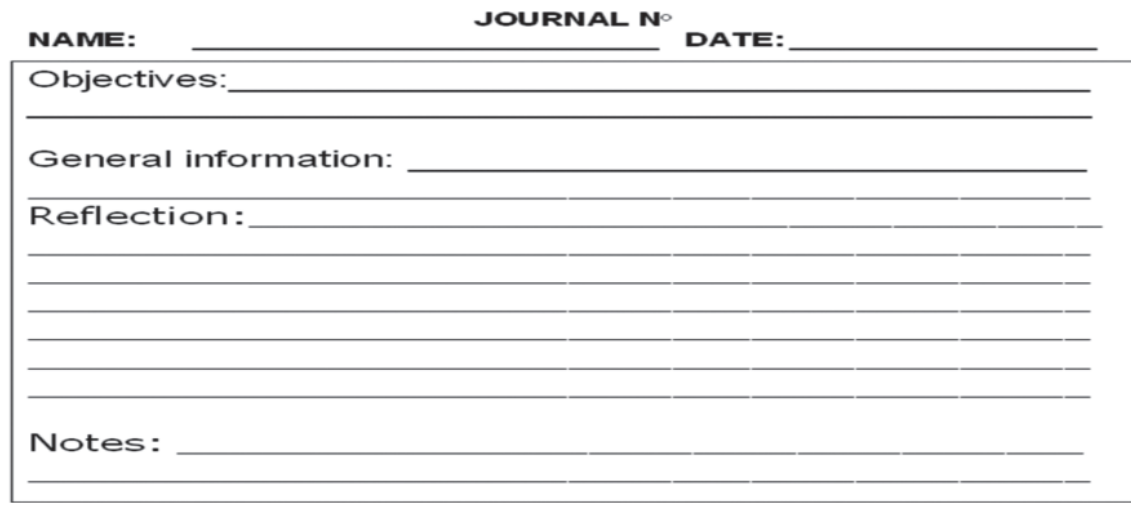




\section{Appendix 5.}

\section{Portfolio format for Student Teachers' Lesson Planning Process Analysis}

Taking into account the chronological sequence of your lesson plans, your points of view and you're counselor's comments, analyze the following aspects.

\begin{tabular}{|l|l|l|l|}
\hline \multicolumn{1}{|c|}{ ASPECTS } & STRENGTHS & WEAKNESSES & FINAL REFLECTION \\
\hline $\begin{array}{l}\text { Formulation of achievements, } \\
\text { functions, topics, competencies } \\
\text { (what showed you the horizon) }\end{array}$ & & & \\
\hline $\begin{array}{l}\text { Coherence in the planning of } \\
\text { steps (warming up, practice, } \\
\text { presentation) }\end{array}$ & & & \\
\hline Sequence of activities & & & \\
\hline Materials/ guides & & & \\
\hline $\begin{array}{l}\text { Application of knowledge about } \\
\text { ELT (English language teaching } \\
\text { methodology, techniques) }\end{array}$ & & & \\
\hline $\begin{array}{l}\text { Variety, suitability of activities } \\
\text { for students, awareness of } \\
\text { students' interests and needs. }\end{array}$ & & & \\
\hline Knowledge of the language & & & \\
\hline Others & & & \\
\hline
\end{tabular}

\section{THE AUTHORS}

JOHN JAIRO VIÁFARA is an associate professor at UPTC in Tunja. He holds a B.Ed in Education (English) from Universidad Nacional de Colombia, a Master in Applied Linguistics (Universidad Distrital) and currently is a Fulbrighter studying his PH.D at The University of Arizona. His interests include pre-service and in-service teacher education, pedagogical research and ELT Methodology.

MARIA EUGENIA LÓPEZ HURTADO holds her B.Ed in Education (English and Spanish) from Universidad Pedagógica Nacional. She is a specialist in Educational Multimedia from Universidad Antonio Nariño. She has a M.A in Applied Linguistics to the Teaching of English as A Foreign Language from Universidad Distrital Francisco José de Caldas. Currently, she teaches English as a foreign language at Universidad Nacional, Universidad Libre. Her fields of interest include e-learning, portfolio design, cooperative learning, hypertext design, English language teaching methodology and educational research. 